\title{
Sciendo
}

DOI: $10.2478 /$ jolace-2019-0010

\section{Chinese TESOL Students' Perception of Their Speaking Anxiety in Workshops}

\author{
Wu Huashan \\ Hubei University, China \\ 798213587@qq.com
}

\begin{abstract}
Foreign language anxiety (FLA) is perceived as a negative factor influencing learners' language achievement. Targeting Chinese overseas students, this paper investigates whether communicative confidence, fear of negative evaluation, attitude towards using English in workshops and trait anxiety are related to Chinese students' speaking anxiety. The present study also aims to examine how students perceive their speaking anxiety and coping strategies both from teachers and students. The questionnaire and the semistructured interview were adopted for data collection. 80 TESOL students at the University of Edinburgh were invited to complete the questionnaires, with 6 students participating in the interviews to get deeper insights into Chinese students' perception of their speaking anxiety. Research findings revealed that communicative confidence, fear of negative evaluation, attitude towards using English in workshops and traits anxiety were strongly related to Chinese students' speaking anxiety. In the interviews, 6 respondents commented that instructors' characteristics, such as patience and humor, and their preparation before class can alleviate their speaking anxiety in workshops. It is hoped that the current study can contribute to a deeper understanding of Chinese students' speaking anxiety in UK universities.
\end{abstract}

Keywords: speaking anxiety; Chinese overseas students; instructors; communicative confidence; fear of negative evaluation; attitude towards using English; trait anxiety

\section{Introduction}

With the internationalization of higher education, an increasing number of Chinese students are pursuing their master's degree in the UK. Chinese students prefer UK educational institutions because of their academic reputation and the chance to improve their English proficiency. Therefore, Chinese students account for the largest proportion of the student population in the UK (Iannelli \& Huang, 2014). According to the British Council (2004), the number of Chinese students in the UK is expected to reach 130,900 in 2020.

However, as the largest proportion of international students in the UK, a common observation about Chinese students' participation in oral-oriented 
activities is their reticence (Liu, 2002). A large body of research attributed students' participation avoidance to their speaking anxiety. Horwitz et al. (1986, p.128) defined foreign language anxiety as 'a distinct complex of self-perceptions, belief, feeling and behaviors related to classroom language learning arising from the uniqueness of the language learning process.' FLA is an umbrella term incorporating four language skills (speaking, writing, listening and reading), yet students do not have an equal amount of anxiety in these four domains (Horwitz, 2016), with speaking being particularly anxiety-provoking (Bailey, 1983; Keramida, 2009; Kim, 2009).

\section{Review of previous research}

Three components of FLA

To analyze FLA in the educational setting, Horwitz et al, (1986) identified three components of language anxiety. They are communication apprehension, fear of negative evaluation and test anxiety. Communication apprehension refers to 'a type of shyness characterized by the fear of communicating with people' (Horwitz et al., 1986, p. 127). Students with communication apprehension feel unease to use the target language when being the focus of others, especially in the speaking context. Communication apprehension is more common in some countries than others. For example, Chinese students are used to being taught by drilling and manipulated activities in which they are likely to be non-vocal (Levinsohn, 2007). With respect to fear of negative evaluation, it refers to 'apprehension about others' evaluation, avoidance of evaluative situations and expectation that others would evaluate oneself negatively' (Horwitz et al., 1986, p.128). Students with fear of negative evaluation regard mistakes and errors as a handicap of the good performance rather than a natural part of the language learning process. This belief impedes oral participation (Yalcin \& Incecay, 2014). As to test anxiety, it is 'a type of performance anxiety stemming from the fear of failure' (Horwitz et al., 1986, p. 127). Students with test anxiety feel afraid to fail in a test situation, especially in the speaking output stage.

To measure the levels of language anxiety, Horwitz et al. (1986) devised the Foreign Language Classroom Anxiety (FLCAS), which consisted of 33 questions indicating communication apprehension, fear of negative evaluation and test anxiety. Learners' levels of language anxiety can be determined by calculating all the responses to the statements in FLCAS. Because of its reliability and validity, FLCAS was widely used in subsequent research regarding foreign language anxiety (Liu, 2006).

\section{Trait anxiety}

In educational research, Horwitz and Young (1991) proposed that FLA can be divided into trait anxiety, state anxiety, and situation-specific anxiety. Trait anxiety 
and state anxiety are both related to innate emotional stability, so students with trait anxiety feel nervous in various conditions. However, situation-specific anxiety is evoked by a particular condition or event, such as presentations and exams (Spielberger, 1983). Distributing questionnaires to 100 students from two faculties, Rahimi and Quraishi (2019) found that introversion resulted in higher speaking anxiety. In an earlier study, Gkonou (2012) maintained that personality facet was an important predictor in language anxiety, while shyness is recognized as one of the typical characteristics of Chinese international students. Ruble and Zhang (2013) conducted a study to examine the stereotypes of Chinese overseas students held by Americans. 100 American students were invited to describe the typical traits of Chinese students, and shyness was the traits most rated by the participants. According to Olakitan (2011), introverts tended to be reticent in oral interaction, as they are apt to steer away from the negative evaluation. Over concern about classmates' and teacher's evaluation is not only the feature of anxious learners but that of perfectionists. This lends support to Ramirez's (1999) findings which claimed that perfectionism-oriented students were concerned about the opinions of others, and it was highly probable that they suffered more from FLA (Dewaele, 2017). In another study, Gregersen and Horwitz (2002) investigated the relationship between language anxiety and perfectionism in the field of oral production, concluding that learners with perfectionism were more ambitious about their language performance. Such demands can foster language anxiety. Nevertheless, some studies indicated that perfectionism had positive effects on language learning (Starley, 2019). Another source of foreign language anxiety is competitiveness with classmates. Bailey (1983) analyzed the journals of eleven students and found that competitiveness was the main reason resulting in language anxiety. Students tend to compare themselves with peers or the idealself in terms of language proficiency when learning a foreign language.

\section{Reasons why FLA occurs}

A great many studies have probed into the factors contributing to learners' FLA, with communication apprehension being a significant predictor (Rassaei, 2015). It is reasonable to assume that students with communication apprehension feel uncertain in speaking English in public owing to their linguistic deficiency. According to Liu and Jackson (2008), learners experiencing communicative apprehension had difficulty in formulating their utterances in the target language and speaking English in front of others.

Besides, Mak (2011) identified fear of negative evaluation as the most obvious factor giving rise to speaking anxiety. Targeting 313 Chinese university students in Hong Kong, the study administrating the Foreign Language Classroom Anxiety Scale (FLCAS) attempted to find out variables bringing about speaking-in-class anxiety. Findings attributed students' speaking anxiety to five influential factors, 
namely fear of negative evaluation, nervousness when communicating with mother-tongue speakers, passive feeling towards the language class, lack of confidence, and fear of failing the exams. Among the 5 aspects, fear of negative evaluation was the most predictive in FLA. Students' speaking apprehension arises from the feeling of embarrassment when they are evaluated negatively by classmates. For example, they may assume that their spoken English would be judged to be accented and unauthentic (Jin \& Dewaele, 2018). Similarly, Gkonou (2012) examined the causes of Greek learners' English anxiety by analyzing 64 entries through qualitative content analysis, finding that fear of negative evaluation was the most salient reason for anxiety.

Students with misguided belief show an inclination to have a higher level of speaking anxiety. Some learners hold that one ought to speak and write without errors, pronounce like a native speaker or learn a foreign language within two years (Ortega, 2009). Certain learners placed great emphasis on accuracy and standard accent, and they supported the notion that some language learners had a special gift to learn foreign languages. Furthermore, teachers' inappropriate instructions about language learning may also provoke anxiety. For example, unsuitable error correction, such as interrupting students in order to correct errors, may easily arouse students' anxiety. In interviews with foreign language specialists, Young (1992) further argued that some other factors having powerful effects on learner anxiety included specific teaching methodology and students' coping skills.

\section{Previous suggestions to deal with anxiety}

It is essential for teachers to be aware of the manifestation of FLA among students. They should not label students who remain quiet with 'lazy' and 'demotivated' when those students are suffering from language anxiety. Trang et al. (2013) surveyed 419 students and 8 English teachers in a Vietnamese university via questionnaires, interviews, as well as student autobiographies, yielding the result that around two-thirds of the students were experiencing FLA, but the teachers paid little attention to the phenomenon. Instead, teachers need to identify students with speaking anxiety and tailor appropriate classroom activities to dent anxiety (Tsiplakides \& Keramida, 2009). A host of studies recommended teachers to incorporate pair work or group work in that it can provide a nonthreatening environment where students may be more motivated to break the silent habit (e.g., Lee, 2002; Tsiplakides \& Keramida, 2009; Humphries et al., 2015). In the pair work context, students no longer feel their oral performance is assessed so that they are more engaged, paying more attention to fluency and communication instead of accuracy. This is in line with Matsuda and Gobel (2004) that underlined the importance of group work in their research, with a great number of informants reporting that they prefer fewer interlocutors in the 
communication. Instructors' temperaments also have a role to play in reducing learners' speaking anxiety. Friendly, patient and humorous teachers are believed to help students alleviate speaking anxiety (Young, 1990; Humphries et al., 2015; Jin et al., 2017), because students have less concern over the negative evaluation and feel at ease to share their opinions in class.

In classroom discussion, starting with familiar topics is perceived to be helpful in an effort to build students' confidence before moving to more challenging topics. However, speaking English around familiar topics is not necessarily easier, because students may lack the relevant lexical resources. For example, it may be still challenging for a Chinese student majoring in medicine to talk about the function of a particular herbal medicine in English. Also, it is essential for students to be prepared, because having to speak in front of the class before fully prepared may multiply anxiety (He, 2013). This is congruent with the research results of $\mathrm{Du}$ (2009). Du (2009) reckoned that there was no point in pushing students to speak before they were ready. Instead, it may cause more anxiety. One way to get students prepared is to provide enough wait-time for them to construct their answers with more reasoning and details. Wait-time is of great importance for Chinese students, because 'face' is valued in Chinese culture (Mak, 2011). If they are under preparation, they would worry about losing face, which is likely to impose great influence on their performance. However, Tsui (2001) proposed that giving excessive wait-time had adverse impacts on speaking anxiety.

Providing positive reinforcement was another technique to help students overcome their anxiety (Kitano, 2001; He, 2013). Apart from verbal praise, Thompson (1997) suggested that non-verbal praise, such as positive gestures, nodding or smiling, was recommended. They treat mistakes as threats and the source of negative evaluation from fellow classmates and the teacher. Thus, instructors need to be cautious about direct error correction in speaking activities in an attempt to improve students' fluency, since instant error correction may damage students' self-confidence (He, 2013). Meanwhile, it is imperative for students to foster the belief that errors are inevitable during language learning (Dornyei, 2001).

The above practice and teaching intervention are drawn upon prior literature on language anxiety for the purpose of creating a comfortable and supportive learning community where students' FLA can be alleviated (Gregersen, 2003). To date, there is a limited amount of research investigating Chinese students' speaking anxiety in the ESL context. Therefore, this exploratory study aims to explore the speaking anxiety of Chinese students studying in the UK and what techniques the students come up with to resolve the difficulties. The following research questions are formulated:

1) What are the main causes of speaking anxiety among Chinese students in interactive activities in workshops? 
2) What do students think instructors can do to help them overcome their speaking anxiety?

3) What do students think they themselves can do to overcome speaking anxiety?

\section{Methodology}

Participants

In this study, 80 Chinese students from the University of Edinburgh were invited to fill the questionnaires and 6 respondents who were most anxious towards speaking English were selected to proceed semi-structured interviews based on the results of the questionnaire. Participants' English proficiency is about upper-intermediate, as they need to meet the English language requirement of the University of Edinburgh, with at least an IELTS score of 7.0.

\section{Instruments}

Questionnaire. The questionnaire was distributed to 80 TESOL students, while 71 questionnaires were valid and 9 questionnaires were deleted either because the time used to complete the questionnaire was less than 100 seconds or the same answer was selected throughout the whole questionnaire. Each participant's score was calculated and frequency of the choice for each statement was also computed. Questionnaire acted as a quantitative method to answer the first research question.

Semi-structured Interview. For exploring the deeper insider perception of speaking anxiety in workshops, 6 high-anxious students were invited to take part in the semi-structured interviews, with each no longer than 20 minutes. The interview recordings were systematically transcribed according to conversation analysis convention (Robson, 2011; Gray, 2014) and anonymized to protect participants' identities. Interview acted as a qualitative method to answer the last two research questions.

\section{Data analysis}

The quantitative result from the questionnaire was computed by means of SPSS with respect to correlation, mean and standard deviation to determine anxiety levels of participants. The qualitative data from interviews were transcribed; thematic analysis was adopted to identify themes, probing into students' perceptions of speaking anxiety in workshops.

\section{Findings and discussion}

Research question1: What are the main causes of speaking anxiety in interactive activities in workshops among Chinese students? 
SPEARMAN correlation coefficients in SPSS were used to identify the relationship between anxiety and four constructs, namely, communication confidence, fear of negative evaluation, attitudes towards using English in class and trait anxiety, and the resulting correlation is shown in Table 1. It is clear that the four constructs are all significantly correlated with students' anxiety levels. Self-report anxiety appears to be able to predict communicative confidence; that is, if participants report low levels of anxiety in the questionnaires, they are likely to have more communicative confidence. By contrast, if participants' speaking anxiety appears to be high, fear of negative evaluation, passive attitude towards using English in class and anxious personality are inclined to be more evident.

Tab. 1: Correlation between speaking anxiety and four constructs

\begin{tabular}{|c|c|c|c|c|c|c|c|}
\hline Variable & Mean & SD & 1 & 2 & 3 & 4 & 5 \\
\hline 1 SPCC & 25.50 & 6.29 & $\begin{array}{l}1.000 \\
71 \\
\end{array}$ & & & & \\
\hline 2 Fearneg & 25.73 & 6.00 & $\begin{array}{l}-.736^{* *} \\
.000 \\
71\end{array}$ & $\begin{array}{l}1.000 \\
71\end{array}$ & & & \\
\hline $\begin{array}{l}3 \\
\text { NegAttitud }\end{array}$ & 23.28 & 5.71 & $\begin{array}{l}-.670^{* *} \\
.000 \\
71\end{array}$ & $\begin{array}{l}.760^{* *} \\
.000 \\
71\end{array}$ & $\begin{array}{l}1.000 \\
71\end{array}$ & & \\
\hline 4 TraitAnx & 25.65 & 6.20 & $\begin{array}{l}-.590^{* *} \\
.000 \\
71\end{array}$ & $\begin{array}{c}.704^{* *} \\
.000 \\
71\end{array}$ & $\begin{array}{l}.593^{* *} \\
.000 \\
71\end{array}$ & $\begin{array}{l}1.000 \\
71\end{array}$ & \\
\hline 5 ANXIETY & 24.00 & 5.06 & $\begin{array}{l}-.607^{* *} \\
.000 \\
71 \\
\end{array}$ & $\begin{array}{l}.499^{* *} \\
.000 \\
71 \\
\end{array}$ & $\begin{array}{l}.432^{* *} \\
.000 \\
71 \\
\end{array}$ & $\begin{array}{l}.480^{* *} \\
.000 \\
71\end{array}$ & $\begin{array}{l}1.000 \\
71\end{array}$ \\
\hline
\end{tabular}

Notes:

SPCC: self-perceived communicative confidence

Fearneg: fear of negative evaluation

NegAttitud: negative attitude towards using English

TraitAnx: trait anxiety

\section{Communicative confidence}

The response showed that there was a negative correlation between communicative confidence and in-class speaking anxiety $(r=-.607, p<.001)$. The median scores of the statements labeled communicative confidence were above the median 3.5, implying that this communicative confidence was an influential factor concerning speaking anxiety. According to Liu and Jackson (2008), learners experiencing communicative apprehension had difficulty in communicating with 
others in the target language and speaking English in front of others. This is known as 'stage fright'. McCroskey (1978) maintained that communicative apprehension was more than stage fright and shyness. It is an unwillingness to interact verbally with peers or teachers. The result of the relationship between communicative confidence and speaking anxiety confirms the findings of Mak (2011) who commented that speech apprehension was the most significant factor contributing to speaking anxiety. Most of the interviewees in the current study expressed that speaking in public and communicating with native speakers increased their anxiety in interactive activities.

... if I speak in front of many people (...) I will feel embarrassed (...) maybe I say something wrong or something like that (...) I think it will make things funny (S3)

... because the way native speakers talk is kind of pushing you and they speak really fast and you just feel hard to keep up with them and because the way you present your opinion looks quite slow and more like juvenile in expression (...) so you will feel less confident to speak (S1)

Four participants in the interviews felt nervous when communicating with native speakers, explaining that the quick speed of native students can easily arouse their speaking anxiety. Aida's (1994) research concluded that uncomfortableness resulting from speaking with mother-tongue speakers was the most rated factor pertaining to speaking anxiety. Nevertheless, in the current study, S6 felt more confident when speaking with locals. The reason why this student felt less anxious seemed to be associated with opportunities to practice before speaking in public.

... when I sit with Chinese people (...) we discuss in Chinese (...) and then when it turns to the public speaking (...) you need to speak English (...) I start panic or anxious (...) however (...) when you firstly discuss with native speakers in English and report in English (...) you will be more confident (...) I don't think anxiety is related to when native speakers sit around you (S6)

\section{Fear of negative evaluation}

The quantitative results indicated that fear of negative evaluation can predict students' speaking anxiety in workshops $(\mathrm{r}=.499, \mathrm{p}=<.001)$. To be more specific, if students thought highly of the evaluation from their classmates, they may have a higher level of speaking anxiety. The findings of this study seemed to corroborate Worde (2003) that adopted quantitative and qualitative research methods to explore participants in three language classrooms (French, German, and Spanish) with regard to their experience and feelings of FLA. Participants cited various sources for their anxiety, and fear of negative evaluation was one of the most 
important factors. They were sensitive to the evaluation of fellow classmates and the teacher, worrying that they looked foolish due to their unsatisfactory performance. Similarly, in the interviews of the present study, students expressed that their concern about the negative evaluation hindered them from participating actively both in workshops and test situations. Oral presentation often acts as an assessment component of a course. In other words, their performance in the oral presentation is a crucial part in determining the final results. Hence, they were haunted by the idea that flawed grammar and poor English made the instructor have a negative evaluation on them.

... when I speak English (.) I care much about the grammar part and I am afraid that others will think my English is very poor (...) especially my grammar part which I am not confident (S2)

I am afraid that other people will look down on me if I do not perform very well (S5)

Research on learners' speaking anxiety showed that highly anxious students were prone to protect their good image by withdrawing from the classroom interaction (Mak, 2011; Gkonou, 2012; Yalcin \& Incecay, 2014; Rahimi \& Quraishi, 2019). However, their avoidance of participation is likely to form a 'vicious cycle' as they do not seize the opportunities to practice their speaking, which in turn contributes to their higher level of anxiety.

\section{Trait anxiety}

In accordance with the data, it is apparent that there was a significant correlation between trait anxiety and in-class speaking anxiety $(r=.480, p<.001)$. Table 2 illustrates the frequency of the choice for three trait anxiety statements, including shyness, competitiveness, and perfectionism.

Tab. 2: A frequency count of the choice for three trait anxiety statements

\begin{tabular}{|c|c|c|c|c|}
\hline Statements & Response & Count & Frequency & total \\
\hline \multirow{3}{*}{$\begin{array}{l}\text { 1. I see myself as } \\
\text { someone who is } \\
\text { sometimes shy and } \\
\text { inhibited, so I am easily } \\
\text { nervous when I have to } \\
\text { speak in front of the } \\
\text { class. }\end{array}$} & $\begin{array}{l}\text { Strongly } \\
\text { agree }\end{array}$ & 11 & $15.49 \%$ & \multirow[t]{3}{*}{$\begin{array}{l}44 \\
(61.97 \%)\end{array}$} \\
\hline & $\begin{array}{l}\text { Moderately } \\
\text { agree }\end{array}$ & 15 & $21.13 \%$ & \\
\hline & Slightly agree & 18 & $25.35 \%$ & \\
\hline $\begin{array}{l}\text { 2. Even if I am well- } \\
\text { prepared for the class, I }\end{array}$ & $\begin{array}{l}\text { Strongly } \\
\text { agree }\end{array}$ & 3 & $4.23 \%$ & $35(49.3 \%)$ \\
\hline
\end{tabular}




\begin{tabular}{|c|c|c|c|c|}
\hline \multirow[t]{2}{*}{$\begin{array}{l}\text { still feel anxious about } \\
\text { it. }\end{array}$} & $\begin{array}{l}\text { Moderately } \\
\text { agree }\end{array}$ & 13 & $18.31 \%$ & \\
\hline & Slightly agree & 19 & $26.76 \%$ & \\
\hline \multirow{3}{*}{$\begin{array}{l}\text { 3. If other group } \\
\text { members' English is } \\
\text { better than me, I will } \\
\text { feel nervous when I } \\
\text { speak English. }\end{array}$} & $\begin{array}{l}\text { Strongly } \\
\text { agree }\end{array}$ & 3 & $4.23 \%$ & \multirow[t]{3}{*}{$\begin{array}{l}44 \\
(61.97 \%)\end{array}$} \\
\hline & $\begin{array}{l}\text { Moderately } \\
\text { agree }\end{array}$ & 17 & $23.94 \%$ & \\
\hline & Slightly agree & 24 & $33.8 \%$ & \\
\hline
\end{tabular}

In this research, 44 out of 71 participants deemed that their introverted personality was the major contributor to speaking anxiety in workshops. On the contrary, those considering themselves as the extroverted were more relaxed in the speaking session. Sociability, excitement, and optimism are the labels of extroverts, whereas introverts have the tendency to stay reticent (Olakitan, 2011), which explains why introverted students' engagement is less active in workshops. In the interview, all of the respondents perceived themselves as introverted. They remarked that shyness made them panic when speaking in front of the class.

I am very shy, so when I speak in front of the class (...) I would feel really anxious (...) while extroverted students feel very ease and they are always active in the class (S5)

On the basis of the quantitative results, approximately $50 \%$ of participants noted that even if they were well-prepared for the class, they were still anxious in workshops. One of the explanations is that students with perfectionism may react strongly to mistakes they make, because they cared about the others' evaluation (Gregersen \& Horwitz, 2002; Dewaele, 2017; Rahimi \& Quraishi, 2019). In contrast, those who felt sure and relaxed when they were well-prepared had less anxiety.

I am a detailed-oriented person (...) I know many people are perfectionists (...) for example (...) when I speak English (...) I care about the grammar (...) structure of the sentences and proper words used (S2)

This interviewee contended that her detail-oriented behavior can be manifested from her over-concern about grammar, sentence structures and use of the words. Gregersen and Horwitz (2002) had a similar research result. They undertook an interview study among 8 university students in Chile to clarify the relationship between perfectionism and FLA. The research results showed that language anxiety was likely to stem from perfectionism, concluding that anxious learners tended to strive to achieve accuracy and perfection. Perfectionists ought to develop a realistic expectation and take a more relaxing attitude towards the 
mistakes in their spoken English. A word of caution is in order however. Only a few learning groups at a certain language learning stage were involved as participants in Gregersen and Horwitz's research, which can not generalize the findings among the wider population.

Apart from shyness and perfectionism, competitiveness is brought up in the questionnaire. The quantitative result showed that 44 out of 71 participants felt nervous when speaking English on condition that other group members' English was better. Bailey (1983) maintained that competitiveness may lead to anxiety when students compared themselves with classmates or an ideal self. In the interview of the present research, one of the respondents expressed that he was anxious and less confident when he compared himself with proficient English learners. As Bailey (1983) insisted, heavy ego-involvement was likely to engender language anxiety.

... sometimes (...) I think I am a person who tend to compete with others (...) so when there is a group member who is very competent (...) I will feel anxious because I am not the best one in the group (...) this makes me feel down (S5)

Negative attitudes towards using English in class

The current study found that passive attitude towards using English in class was predictive in speaking anxiety $(\mathrm{r}=.432, \mathrm{p}<.001)$, suggesting that anxious students were less likely to speak English in class. Put it differently, students' negative attitudes towards using English in class can exacerbate their speaking anxiety in workshops, because passive attitudes negatively affected oral performance when they were required to engage in a discussion.

... actually (...) I would never raise my hand to answer questions raised by teachers (...) because I think it is too awkward (...) I am afraid to give a wrong answer (...) and then I would feel very embarrassed (...) so I prefer to remain silent (...) and also (...) when I discuss a question with Chinese students in the workshops (...) I always use Mandarin (S5)

In the interview, 3 students stated that they had a tendency to avoid speaking English in workshops. One of the reasons accounting for the negative attitude was the lack of confidence in self-perceived English proficiency. The finding of negative attitude towards using English in this study echoes Mak (2011) that explored causes of the speaking anxiety among 313 Chinese students in a Hong Kong university, with FLCAS used as the data collecting instrument. It turned out that negative attitude towards using English was identified as one of the explanations for speaking anxiety. Those who held a negative attitude towards using English in class assumed that others were better English speakers, so they applied speaking avoidance strategy. 


\section{Research question 2: What do students think instructors can do to help them overcome speaking anxiety?}

During the interview, students were asked to comment on what instructors can do to alleviate their speaking anxiety. These six interviewees' discourse was grouped into three categories: classroom activities design, characteristics of instructors and facilitating role of instructors (Table 3).

\section{Classroom activities design}

Participants in the current study reported that working in a small group or not being called out to answer questions can largely decrease their speaking anxiety. Three interviewees pointed out that letting students answer questions voluntarily can effectively make speaking less-threatening.

... organizing some interesting games in class (...) and encouraging us to speak English in these activities instead of call on students and ask questions and ask him or her to answer (S4)

From the response of the interviewees, when students were singled out by the instructor, their speaking anxiety would climb dramatically. However, organizing pair work and group work can create a supportive climate for students to discuss in workshops. This is consistent with Humphries et al., (2015) unveiling that the number of interlocutors appeared to influence learners' speaking anxiety, with most of the informants thinking that they had less anxiety when there were a few interlocutors in the communication. This is because they did not have to worry that their grammar mistakes would be judged by their classmates, and they were more comfortable to express their ideas without stammering (Matsuda \& Gobel, 2004).

Reducing students' speaking anxiety by giving them opportunities to volunteer and organizing pair work and group work lends support to Young's (1990) research in which students acknowledged that instructors can alleviate their anxiety by letting them provide responses voluntarily rather than call the roll call. In addition, they further commented that working in a small group was anxietyreducing. One respondent in Young's research reported that not being in an examination situation can mediate her speaking anxiety, which corresponds to one of the interviewees in current study.

... when I have the individual difference class (...) there is a part to deliver oral presentation on an article we find (...) generally (...) there are four or three people in a group, and they will be asked to give the oral presentation (...) but the instructor clearly states that it will not be evaluated or given marks (...) I think that alleviates my anxiety (S2) 
Test anxiety is a component of FLA, and it is associated with performance anxiety resulting from the fear of failing to perform satisfyingly (Liu \& Jackson, 2008). Students put too much expectation on them and worry that they are not capable of achieving their targets (Yalçın \& İnceçay, 2014). When students are in a test situation where their oral production is evaluated by the instructor, they would easily feel anxious, which inhibits them from achieving the expected results. Thus, to help students perform by decreasing the influence of test anxiety, teachers could avoid putting students in test-alike situations.

\section{Characteristics of instructors}

The following three extracts represent three characteristics of instructors: patient, friendly and humorous. In light of the interviewees, if the instructor was patient, students may suppose their spoken English and flawed grammar were understood. With teachers being friendly, students were more likely to share their opinions and were concerned less about negative evaluation. Humorous instructors can make the classroom atmosphere more active, thereby facilitating students' oral output.

... because English is not my first language (...) when I talk about it, the speed is not fluent when I speak (...) so if they are patient about it (...) I think that will comfort me a lot (S2)

... if the teacher is very friendly (...) I would like to share my opinion and I will feel less anxious (...) but if the teacher is very strict and I will feel very nervous (...) I will think she or he will judge my answers (S4)

... having a sense of humor is very important (...) if the instructor can make me laugh in class (...) I will not feel very stressful (S5)

The finding of instructors' characteristics of this study is in conformity with Jin et al.'s (2017) research where students praised instructors' certain characteristics, such as dedication, humor, amicability, and patience, which can help to create a supportive classroom atmosphere, encouraging students to express themselves regardless of speaking anxiety. Instructors should project themselves as workshop facilitators instead of powerful teachers assessing students' performance (GhorbanDordinejad \& Nasab, 2013).

\section{Facilitating role of instructors}

Instructors can act as facilitating roles by giving praise, eye contact, and positive gestures to encourage and motivate students. According to interviewees, if instructors give positive reinforcement, it would boost students' confidence and mediate anxiety level. 
Interviewer: what practices do your instructors engage in to help you alleviate speaking anxiety?

S3: ... maybe just tell students that they are great and encourage students.

Students experiencing fear of negative evaluation prefer to stay silent and avoid taking part in speaking activities, because they regard the language errors as a threat of their good images as well as a source of negative evaluation. Therefore, positive reinforcement, such as positive comments and smiling, can act as an indication of encouragement, thereby strengthening students' confidence (He, 2013). Apart from positive reinforcement, S6 mentioned that if the instructors shared their experience of speaking anxiety with students, it could help to lower anxiety. This is because sharing a similar experience can make the students aware that speaking anxiety is prevalent among learners, so students would become less stressful when they need to speak in front of the class. Oxford (1990) also encouraged students to discuss anxiety with others and keep a journal to record their anxiety.

... there is one course called the individual difference (...) the teacher tries to let us understand everyone has the anxious moment (...) and we are not the only one (...) he kind of makes a common sense that everyone is anxious and do not think it is a big thing (...) try to accept that (S6)

\section{Research question 3: What do students think themselves can do to overcome speaking anxiety?}

In the interview, respondents were asked about the strategies they used to cope with speaking anxiety in workshops. The six interviewees' comments were grouped into three categories: preparation, positive thinking and relaxation techniques (Table 3).

\section{Preparation}

Emerging from the data, all the interviewees expressed that they would be more relaxed if they prepared the lesson beforehand, which is consistent with $\mathrm{Du}$ (2009) and He (2013). The reason is that they may have written some notes which can aid them in performing oral tasks. To encourage students to prepare in advance, teachers can come up with some tactics to reward those having prepared. For example, a short quiz before the class may motivate students to preview the reading materials.

... before the workshops (...) I will prepare for the lesson and the topic discussed in the workshop (...) in the class (...) there are some time leaving for us to think about the questions (...) I will write some notes on the paper (...) so when I am speaking (...) I know exactly what I am talking about (S2) 
... maybe prepare before the workshop will help me to alleviate my anxiety (...) because I have something to share instead of preparing immediately in the workshop (S4)

If a question is posed during the class and students have not prepared for the question before the workshops, teachers are better off giving students appropriate wait-time to process the question and formulate their answers. Wait-time is culturally important for Chinese students in the English class owing to the 'facesaving mechanism' (Mak, 2011). Hence, Chinese students usually feel anxious when they become the focus of attention. If they are not fully prepared, their fear of losing face may give rise to debilitating anxiety. In this regard, instructors need to be aware of their students' psychological state and assist students instead of putting them on the spot before they were well-prepared (He, 2013; Ingram \& Elliott, 2014), this stance being incongruent with Tsui (2001) who noticed that excessive wait-time may exacerbate students' anxiety.

\section{Positive thinking}

Positive thinking, such as self-talk, is an anxiety-coping strategy mentioned by all interviewees. Self-talk is particularly useful in evaluative situations. S5 gave an example of positive self-talk.

... before the presentation (...) I am really anxious (...) then I would talk to the person next to me and avoid thinking about the presentation (...) and I will tell myself that I have rehearsed so many times before (...) so I can handle it (S5)

In another study, Shi et al. (2014) investigated how self-talk was related to public speaking anxiety. The participants were 209 undergraduate students who chose public speaking as an optional course in an American university. Self-Talk Scale and McCroskey et al.'s (1985) Personal Report of Communication Apprehension were used as instruments to measure the frequency of self-talk as well as public speaking anxiety. Research results uncovered that reinforcing selftalk can help to regulate individuals' anxious emotion so as to improve speech performance, which mirrored the conclusions drawn by Fallah (2017) maintaining that self-talk had a positive impact on managing speaking anxiety.

\section{Relaxation techniques}

In addition to preparation and self-talk, relaxation techniques were also mentioned by interviewees. Relaxation techniques include deep breathing, a quick walk and listening to music. However, little previous literature has investigated the relaxation techniques used for coping with speaking anxiety. One exception is the study of Oxford (1990) claiming that anxiety reduction techniques, such as 
deep breathing, music meditation, and physical movement, can help to alleviate anxiety, though Oxford (1990) grouped the relaxation techniques as one of the language learning strategies that learners can apply to enhance the learning process. The later research by Martirossian and Hartoonian (2015) uncovered that FLA related negatively with self-regulation. According to an interviewee in current research, moving around before workshops would effectively manage her anxiety. Similarly, oral presenters can take a deep breath before presenting, and music can be played before having classes.

... in the individual difference workshop (...) a teacher asks students to do physical movement before the class (...) like ask students to stand and make some physical movement and then students will feel less anxious (...) for me (...) if I try to move around instead of sitting still (...) I will feel less anxious (...) I think it works (S6)

Another strategy used by one interviewee was to improve their spoken English. This interviewee felt it was crucial to keep practicing speaking English in an attempt to improve spoken English. Perseverance played a pivotal role in improving language proficiency. If students improve their English proficiency, they would be more confident in speaking English. Being in the UK gives students more opportunities to practice their spoken English.

I think keeping practicing spoken English is the best way to solve the speaking anxiety (...) actually (...) we are in the UK now (...) so we have advantages to practice our speaking with the native speaker (...) living in the UK is really a good chance (S5)

\section{Conclusion}

The results of the present study showed that speaking anxiety commonly existed among Chinese international students, and pedagogical implications are discussed for lowering FLA among Chinese ESL learners. It is pivotal for instructors to be aware of the existence of students' speaking anxiety and equip themselves with knowledge about speaking anxiety, thereby creating a supportive and comfortable atmosphere in workshops. Appropriate speaking activities, such as group work and pair work, can help students to manage speaking anxiety since students are less concerned about their mistakes and negative evaluation in a lessthreatening culture. Students' speaking anxiety may originate from the fear of negative evaluation, so providing positive reinforcement is another way to motivate students. In accordance with interviewees in the present study, they commented that instructors' characteristics, such as patience, friendliness, and humor, can create a supportive classroom atmosphere and encourage students to 
express themselves in workshops. Students' sufficient preparation for course content may also reduce their speaking anxiety.

Tab. 3: Summary of the self-report details from interviews

\begin{tabular}{|c|c|c|c|}
\hline Ss & $\begin{array}{l}\text { Reasons for speaking } \\
\text { anxiety }\end{array}$ & $\begin{array}{l}\text { How can instructors } \\
\text { help to alleviate } \\
\text { speaking anxiety }\end{array}$ & $\begin{array}{l}\text { How do } \\
\text { students deal } \\
\text { with speaking } \\
\text { anxiety }\end{array}$ \\
\hline S1 & $\begin{array}{l}\text { *Poor spoken English } \\
\text { *Afraid of making mistakes } \\
\text { *Shyness } \\
\text { *Speak with native speakers } \\
\text { *Not familiar with } \\
\text { classmates }\end{array}$ & $\begin{array}{l}\text { *Be patient and } \\
\text { friendly } \\
\text { *Let students answer } \\
\text { questions voluntarily } \\
\text { *Speak slowly }\end{array}$ & $\begin{array}{l}* \text { Preparation } \\
* \text { Write notes }\end{array}$ \\
\hline S2 & $\begin{array}{l}\text { *Afraid of making mistakes } \\
\text { *Perfectionism and shyness } \\
\text { *Speak with native speakers }\end{array}$ & $\begin{array}{l}\text { *Be patient and } \\
\text { humorous } \\
\text { *Avoid a test situation } \\
\text { *Give task beforehand }\end{array}$ & $\begin{array}{l}\text { *Preparation } \\
\text { *Write notes }\end{array}$ \\
\hline S3 & $\begin{array}{l}\text { *Poor spoken English } \\
\text { *Speak in public } \\
\text { *Afraid of making mistakes } \\
\text { *Shyness } \\
\text { *Speak with native speakers }\end{array}$ & $\begin{array}{l}* \text { Be patient and } \\
\text { outgoing } \\
{ }^{*} \text { Give positive } \\
\text { reinforcement } \\
{ }^{*} \text { Give useful advice }\end{array}$ & $\begin{array}{l}\text { *Preparation } \\
* \text { Positive self- } \\
\text { talk }\end{array}$ \\
\hline S4 & $\begin{array}{l}\text { *Not familiar with } \\
\text { classmates } \\
\text { *Not well-prepared }\end{array}$ & $\begin{array}{l}\text { *Be patient and } \\
\text { friendly } \\
* \text { Let students answer } \\
\text { questions voluntarily } \\
\text { *Organize group work }\end{array}$ & $\begin{array}{l}* \text { Preparation } \\
* \text { Discuss in } \\
\text { group }\end{array}$ \\
\hline S5 & $\begin{array}{l}\text { *Fear of negative evaluation } \\
\text { *Poor spoken English } \\
\text { *Speak in public } \\
\text { *Speak with native speakers } \\
\text { *Be shy and competitive }\end{array}$ & $\begin{array}{l}\text { *Be patient and } \\
\text { humorous } \\
\text { *Organize group work } \\
\text { *Share the same } \\
\text { experience }\end{array}$ & $\begin{array}{l}\text { *Preparation } \\
\text { *Improve } \\
\text { spoken English }\end{array}$ \\
\hline S6 & $\begin{array}{l}\text { *Speak in public } \\
\text { *Fear of negative evaluation } \\
\text { *Anxious person }\end{array}$ & $\begin{array}{l}\text { *Be patient and } \\
\text { friendly } \\
\text { *Share the same } \\
\text { experience } \\
\text { *Physical movement }\end{array}$ & $\begin{array}{l}* \text { Preparation } \\
* \text { Relaxation } \\
\text { techniques }\end{array}$ \\
\hline
\end{tabular}


This research is limited by the methods adopted to answer the research questions. The self-report questionnaire may not be sufficient to examine Chinese students' speaking anxiety in workshops, even though the follow-up interviews were conducted to delve into more insights. The reason lies in the discrepancy between what participants think they would do and what they would actually do. In this case, structured observation is recommended as an additional approach to examine students' speaking anxiety. Furthermore, whether other variables, such as gender and English proficiency, would exert an influence on Chinese students' speaking anxiety has not been addressed in the current study. Further research considering factors which are not examined in the present study may contribute to a fuller understanding of speaking anxiety.

\section{References}

Aida, Y. (1994). Examination of Horwitz, Horwitz and Cope's construct of foreign language anxiety: the case of students of Japanese. Modern Language Journal, 78(2), 155-168.

Bailey, K.M. (1983). Competitiveness and anxiety in second language learning: looking at and through the diary studies. In H. W. Seliger \& M. H. Long (Eds.) Classroom-oriented Research in Second Language Acquisition. Rowley. MA: Newbury House.

British Council. (2004). Vision 2020: Forecasting International Students Mobility: A UK Perspective. London: British Council.

Dewaele, J.M. (2017). Are perfectionists more anxious foreign language learners and users? In C. Gkonou, M. Daubney, \& J.-M. Dewaele (Eds.), New insights into language anxiety: Theory, research and educational implications (pp. 70-90). Bristol, UK: Multilingual Matters.

Dornyei, Z. (2001). Motivational Strategies in the Language Classroom. Cambridge: Cambridge University Press.

$\mathrm{Du}, \mathrm{X}$. (2009). The affective filter in second language teaching. Asian Social Science, $5,162-165$.

Fallah, N. (2017). Mindfulness, coping self-efficacy and foreign language anxiety: A mediation analysis. Educational Psychology, 37, 745-756.

GhorbanDordinejad, F. \& Nasado, A.H.F. (2013). Examination of the relationship between perfectionism and English achievement as mediated by foreign language classroom anxiety. Asia Pacific Education Review, 14(4), 603-614.

Gkonou, C. (2012). A diary on the causes of English language classroom anxiety. International Journal of English Studies, 13(1), 51-68.

Gray, D.E. (2014). Doing Research in the Real World. Sage.

Gregersen, T. \& Horwitz, E.K. (2002). Language learning and perfectionism: anxious and non-anxious learners' reactions to their own oral performance. The Modern Language Journal, 86(4), 562-570. 
Gregersen, T.S. (2003). To Err is Human: A reminder to teachers of language anxious students. Foreign Language Annuals, 36(1), 25-32.

He, D. (2013). What makes learners anxious while speaking English: a comparative study of the perceptions held by university students and teachers in China. Educational Studies, 39(3), 338-350.

Horwitz, E.K. (2016). Factor structure of the foreign language classroom anxiety scale: Comment on Park (2014). Psychological Reports, 119(1), 71-76.

Horwitz, E.K.; Horwitz, M.B. \& Cope, J. (1986). Foreign language classroom anxiety. The Modern Language Journal, 70(2), 125-132.

Horwitz, E.K. \& Young, D.J. (Eds.) (1991). Language Anxiety: From Theory and Research to Classroom Implications. Englewood Cliffs, NJ: Prentice Hall.

Humphries, S.C., Burns, A., \& Tanaka, T. (2015). "My head became blank and I couldn't speak": Classroom factors that influence English speaking. The Asian Journal of Applied Linguistics, 2(3), 164-175.

Iannelli, C. and Huang, J. (2014). Trends in participation and attainment of Chinese students in UK higher education. Studies in Higher Education, 39(5), 805-822.

Ingram, J., \& Elliott, V. (2014). Turn taking and 'wait time' in classroom interactions. Journal of Pragmatics, 62, 1-12.

Jin, Y., de Bot, K., \& Keijzer, M. (2017). Affective and situational correlates of foreign language proficiency: A study of Chinese university learners of English and Japanese. Studies in Second Language Learning and Teaching, 7(1), 105-125.

Jin, Y.X., \& Dewaele, J.M. (2018). The effect of positive orientation and perceived social support on foreign language classroom anxiety. System, 74, 149-157.

Keramida, A. (2009). Helping students overcome foreign language speaking anxiety in the English classroom: Theoretical issues and practical recommendations. International Education Studies, 2(4), 39-44.

Kim, S.Y. (2009). Questioning the stability of foreign language classroom anxiety and motivation across different classroom contexts. Foreign Language Annals, 42(1), 138-157.

Kitano, K. (2001). Anxiety in the college Japanese language classroom. The Modern Language Journal, 85(4), 549-566.

Lee, I. (2002). Project work made easy in the English classroom. Canadian Modern Language Review, 59(2), 282-290.

Levinsohn, K.R. (2007). Cultural differences and learning styles of Chinese and European trades students. Institute for Learning Styles Journal, 17(1), 12-20.

Liu, J. (2002). Negotiating silence in American classrooms: three Chinese cases. Language and Intercultural Communication, 2(1), 37-54.

Liu, M. (2006). Anxiety in Chinese EFL students at different proficiency levels. System, 34(3), 301-316. 
Liu, M. \& Jackson, J. (2008). An exploration of Chinese EFL learners' unwillingness to communicate and foreign language anxiety. The Modern Language Journal, 92(1), 71-86.

Mak, B. (2011). An exploration of speaking-in-class anxiety with Chinese ESL learners. System, 39(2), 202-214.

Martirossian, A., \& Hartoonian, A. (2015). Lowering foreign language anxiety through self-regulated learning strategy use. English Language Teaching, 8(12), 209-222.

Matsuda, S. \& Gobel, P. (2004). Anxiety and predictors of performance in the foreign language classroom. System, 32(1), 21-36.

McCroskey, J.C. (1978). Oral communication apprehension: a summary of recent theory and research. Human Communication Research, 4(1), 78-96.

McCroskey, J.C., Beatty, M.J., Kearney, P. \& Plax, T. G. (1985). The content validity of the PRCA-24 as a measure of communication apprehension across communication contexts. Communication Quarterly, 33(3), 165-173.

Olakitan, 0.0. (2011). An examination of the impact of selected personality traits on the innovative behaviour of entrepreneurs in Nigeria. International Business and management, 3(2), 112-121.

Ortega, L. (2009). Understanding Second Language Acquisition. New York: Routledge.

Oxford, R. (1990). Language Learning Strategies: What Every Teacher Should Know. New York: Newbury House.

Rahimi, A., \& Quraishi, P. (2019). Investigating EFL Students' Poor Speaking Skills at Kandahar University. American International Journal of Education and Linguistics Research, 2(2), 1-9.

Ramirez, M. (1999). The perfect trap. Psychology Today, 32(2), 30-34.

Rassaei, E. (2015). Oral corrective feedback, foreign language anxiety and L2 development. System, 49, 98-109.

Robson, C. (2011). Real World Research. Wiley.

Ruble, R.A. \& Zhang, Y.B. (2013). Stereotypes of Chinese international students held by Americans. International Journal of Intercultural Relations, 37(2), 202211.

Shi, X., Brinthaupt, T.M. \& McCree, M. (2014). The relationship of self-talk frequency to communication apprehension and public speaking anxiety. Personality and Individual Differences, 75(3), 125-129.

Spielberger, C.D. (1983). Manual for the State-trait Anxiety Inventory. Palo Alto. CA: Consulting Psychologists Press.

Starley, D. (2019). Perfectionism: a challenging but worthwhile research area for educational psychology. Educational Psychology in Practice, 35(2), 121-146.

Thompson, T. (1997). Do we need to train teachers how to administer praise? Selfworth theory says we do. Learning and Instruction, 7(1), 49-63. 
Trang, T., Baldauf, R. \& Moni, K. (2013). Foreign language anxiety: Understanding its status and insiders' awareness and attitudes. TESOL Quarterly, 47(2), 216243.

Tsiplakides, I. \& Keramida, A. (2009). Helping students overcome foreign language speaking anxiety in the English classroom: theoretical issues and practical recommendations. International Education Studies, 4(2), 39-44.

Tsui, A. (2001). Classroom Interaction. In: Carter, R. \& Nunan, D. (Eds). The Cambridge Guide to Teaching English to Speakers of Other Languages. Cambridge: Cambridge University Press.

Worde, V.R. (2003). Students' perspectives on foreign language anxiety. Inquiry, 18(1), n1.

Yalcin, 0. \& Incecay, V. (2014). Foreign language speaking anxiety: the case of spontaneous speaking activities. Social and Behavioural Sciences, 116, 2620 2624.

Young, D.J. (1990). An investigation of students' perspectives on anxiety and speaking. Foreign Language Annals, 23(6), 539-553.

Young, D.J. (1991). Creating a low-anxiety classroom environment: What does language anxiety research suggest? The Modern Language Journal, 75(4), 426439.

Young. D.J. (1992). Language anxiety from the foreign language specialists' perspective: interviews with Krashen, Omaggio Hadley, Terrell and Rardin. Foreign Language Annuals, 25(2), 157-172.

\section{Contact}

Wu Huashan

Hubei University

No. 368, Youyi Road

Wuchang District

Wuhan City

430062 Hubei Province

People's Republic of China 


\section{APPENDICES}

\section{Appendix 1: Information Sheet - How anxious are you?}

\section{Introduction}

I would like to invite you to participate in this study which is concerned with your language anxiety in workshops. I am also interested in the ways your instructors and you use to deal with the speaking anxiety.

\section{Why am I doing the project?}

It is hoped that the research could provide new insights for the speaking anxiety and the advice and techniques to overcome the anxiety.

\section{What will you have to do if you agree to take part?}

1. You will be invited to complete an online questionnaire.

2. If you are selected to participate the interview, we will arrange a time to meet in your own accommodation if it is convenient for you. I will ask you questions about your speaking anxiety in workshops during the interview, and it will be recorded.

\section{How much of your time will participation involve?}

It should not take more than 10 minutes to complete the questionnaire. The interview lasts no more than twenty minutes.

\section{Will your participation in the project remain confidential?}

If you agree to take part, you can be assured that you will remain anonymous.

\section{Are there any disadvantages of taking part?}

You may feel uncomfortable talking about your speaking anxiety. If you are uncomfortable, you are welcome to stop the interview at any point.

\section{Is participation voluntary?}

Yes, your participation in this study is entirely voluntary. If you do agree to participate you are free to withdraw at any time during the project if you change your mind. 


\section{Appendix 2: Questionnaire}

\section{How anxious are you?}

Hi! I would like to invite you to participate in this questionnaire which is concerned with your speaking anxiety in workshops. The questionnaire is divided into two parts. The first part is questions regarding general perception of your speaking anxiety in workshops. The second part is to collect demographic information.

\section{Participants:}

The current research focuses on Chinese students studying in the UK.

\section{Confidentiality:}

If you agree to take part, you can be assured that you will remain anonymous.

If you are willing to participate the followed-up interview, please leave your email address at the end of the questionnaire.

Many thanks :)

\section{Part 1}

1. I get nervous and confused when speaking English in class.

Strongly agree

Moderately agree

Slightly agree

Neither agree nor disagree

Slightly disagree

Moderately disagree

Strongly disagree

2. In my opinion, other students speak English better than I do.

Strongly agree

Moderately agree

Slightly agree

Neither agree nor disagree

Slightly disagree

Moderately disagree

Strongly disagree

3. It frightens me when I do not understand what the teacher and other students are saying in English.

Strongly agree

Moderately agree

Slightly agree 
Neither agree nor disagree

Slightly disagree

Moderately disagree

Strongly disagree

4. I see myself as someone who is shy, so speaking in front of the class makes me nervous.

Strongly agree

Moderately agree

Slightly agree

Neither agree nor disagree

Slightly disagree

Moderately disagree

Strongly disagree

5. I feel at ease when speaking English with mother tongue speakers.

Strongly agree

Moderately agree

Slightly agree

Neither agree nor disagree

Slightly disagree

Moderately disagree

Strongly disagree

6. Having my spoken English assessed by the teacher in class is fine.

Strongly agree

Moderately agree

Slightly agree

Neither agree nor disagree

Slightly disagree

Moderately disagree

Strongly disagree

7. I feel ease when speaking English in the class.

Strongly agree

Moderately agree

Slightly agree

Neither agree nor disagree

Slightly disagree

Moderately disagree

Strongly disagree 
8. I feel comfortable if other students in the group are competent.

Strongly agree

Moderately agree

Slightly agree

Neither agree nor disagree

Slightly disagree

Moderately disagree

Strongly disagree

9. I feel uncertain when speaking English in class.

Strongly agree

Moderately agree

Slightly agree

Neither agree nor disagree

Slightly disagree

Moderately disagree

Strongly disagree

10. I am afraid that other students will laugh at me when I speak English.

Strongly agree

Moderately agree

Slightly agree

Neither agree nor disagree

Slightly disagree

Moderately disagree

Strongly disagree

11. it embarrasses me to volunteer answers in class.

Strongly agree

Moderately agree

Slightly agree

Neither agree nor disagree

Slightly disagree

Moderately disagree

Strongly disagree

12. Even if I am well-prepared for class, I still feel anxious about it.

Strongly agree

Moderately agree

Slightly agree

Neither agree nor disagree 
Slightly disagree

Moderately disagree

Strongly disagree

13. I feel confident in speaking English in class.

Strongly agree

Moderately agree

Slightly agree

Neither agree nor disagree

Slightly disagree

Moderately disagree

Strongly disagree

14. Actively taking part in classroom activities improves my English speaking.

Strongly agree

Moderately agree

Slightly agree

Neither agree nor disagree

Slightly disagree

Moderately disagree

Strongly disagree

15. I am willing to volunteer to answer questions in class.

Strongly agree

Moderately agree

Slightly agree

Neither agree nor disagree

Slightly disagree

Moderately disagree

Strongly disagree

16. I feel confident when I am well-prepared.

Strongly agree

Moderately agree

Slightly agree

Neither agree nor disagree

Slightly disagree

Moderately disagree

Strongly disagree 
17. I get nervous when I communicate with mother tongue speakers.

Strongly agree

Moderately agree

Slightly agree

Neither agree nor disagree

Slightly disagree

Moderately disagree

Strongly disagree

18. Having my spoken English assessed in class frightens me.

Strongly agree

Moderately agree

Slightly agree

Neither agree nor disagree

Slightly disagree

Moderately disagree

Strongly disagree

19. I can feel my heart pounding when I am going to be called on in class.

Strongly agree

Moderately agree

Slightly agree

Neither agree nor disagree

Slightly disagree

Moderately disagree

Strongly disagree

20. If other group members' English is better than mine, I feel nervous speaking English.

Strongly agree

Moderately agree

Slightly agree

Neither agree nor disagree

Slightly disagree

Moderately disagree

Strongly disagree

21. I am willing to speak more English in class.

Strongly agree

Moderately agree

Slightly agree 
Neither agree nor disagree

Slightly disagree

Moderately disagree

Strongly disagree

22. I am willing to speak English with other students.

Strongly agree

Moderately agree

Slightly agree

Neither agree nor disagree

Slightly disagree

Moderately disagree

Strongly disagree

23. I do not understand why some people get so upset over speaking English in class.

Strongly agree

Moderately agree

Slightly agree

Neither agree nor disagree

Slightly disagree

Moderately disagree

Strongly disagree

24. I see myself as someone who is outgoing, so I feel relaxed speaking in front of the class.

Strongly agree

Moderately agree

Slightly agree

Neither agree nor disagree

Slightly disagree

Moderately disagree

Strongly disagree

Part 2: Background information

Are you male/ female?

How old are you?

What other languages do you know or use?

Is there anything else you want to add?

Your email address: 


\section{Appendix 3: Questionnaire Constructs}

Communication confidence

1. I get nervous and confused when I am speaking English in class.

2. I never feel quite sure of myself when I am speaking English in class.

3. I get nervous when I communicate with native speakers.

4. It would not bother me at all to speak more English in class.

5. I feel confident when I speak English in class.

6. I would not be nervous when speaking English with native speakers.

Fear of negative evaluation

1. I always feel that other students speak English better than I do.

2. I am afraid that other students will laugh at me when I speak English.

3. It frightens me when I am assessed by speaking English in the class.

4. I am willing to speak English with other students.

5. I believe that my speaking will improve if I take part in classroom activities actively.

6. I do not worry about being assessed by the teacher in class.

Attitudes towards using English in class

1. It frightens me when I do not understand what the teacher and other students are saying in English.

2. it embarrasses me to volunteer answers in class.

3. I can feel my heart pounding when I am going to be called on in class.

4. I do not understand why some people get so upset over speaking English in class.

5. I am willing to volunteer to answer questions in class.

6. I feel ease when speaking English in the class.

Personality trait (perfectionist, competitive and shyness)

1. I see myself as someone who is sometimes shy and inhibited, so I am easily nervous when I have to speak in front of the class.

2. Even if I am well-prepared for the class, I still feel anxious about it.

3. If other group members' English if better than me, I will feel nervous when I speak English.

4. I see myself as someone who is outgoing and sociable, so I do not feel nervous when I have to speak in front of the class.

5. When I am on the way to class, I feel very sure and relaxed if I am well-prepared for the class.

6. I will not feel anxious if other students in the group are competent. 


\section{Appendix 4: Interview Questions}

1. How frequently do you participate in speaking activities in workshops voluntarily?

2. How do you feel when you have to speak English in workshops? [If they do not mention anxiety] Do you ever feel anxious about speaking English in class?

3. What makes you feel anxious about speaking English in class?

4. What do you do to alleviate anxiety during speaking activities in workshops?

5. To what extent do you think personality affects your speaking anxiety? (selfperceived)

6. What factors influence your oral performance in class?

7. What do you do to deal with your speaking anxiety?

8. What characteristics or personalities of instructors help you to reduce speaking anxiety?

9. What practices do your instructors engage in to help you alleviate speaking anxiety?

10. What other practices could instructors do to help you with your speaking anxiety?

11. Is there anything else you would like to tell me about anxiety in language learning class?

\section{Appendix 5: Interview Transcription}

The interview transcription and thematic analysis are available from the author on request. 